\title{
Dose Analysis in Boron Neutron-capture Cancer Therapy (BNCT) Neutron Generator Based for Breast Cancer
}

\author{
Rawi Pramusinta ${ }^{1}$, R. Zailani ${ }^{2}$, Y. Sardjono ${ }^{3 *}$ \\ ${ }^{l}$ Yogyakarta State University, DIY, Indonesia \\ ${ }^{2}$ Semarang State University, Semarang, Indonesia \\ ${ }^{3}$ National Nuclear Energy Agency, DIY, Indonesia
}

\section{ARTICLE INFO}

Article history:

Received: 5 August 2018

Received in revised form: 1 October 2018

Accepted: 1 January 2019

\section{Keywords:}

Keyword Boron dose BNCT

Keyword Breast Cancer

Keyword MCNPX

Keyword Neutron Generator

\begin{abstract}
A B S T R A C T
The purpose of this study is to know the concentration of boron and irradiation times which optimizes the treatment of breast cancer using the BNCT method. This research was conducted by using MCNPX simulation which outputs are flux neutron, neutron scattering dose and gamma dose. The neutron source used is the BSA D-D Neutron generator model. The independent variable of this research is the boron concentration injected into the cancer. The dependent variable is the total dose rate and irradiation time which determines the effectiveness of BNCT therapy. The controlled variables are the output of the neutron flux, dose and gamma neutron scattering dose. The results showed that in the range of $70-150 \mu \mathrm{g} / \mathrm{g}$, the dose rate received by cancer increases with increasing the concentration of boron-10. If the dose rate is increased, the irradiation time interval will be faster. The Boron dose of $70 \mu \mathrm{g} / \mathrm{g}$ and the dose rate of irradiation $0.00293603 \mathrm{~Gy} / \mathrm{sec}$ needs an irradiation time of 409.43 minutes; the boron dose of $90 \mu \mathrm{g} / \mathrm{g}$ and the dose rate of irradiation $0.00241049 \mathrm{~Gy} / \mathrm{sec}$ needs an irradiation time of 345.71 minutes; the boron dose of $110 \mu \mathrm{g} / \mathrm{g}$ and the dose rate of irradiation $0.00271236 \mathrm{~Gy} / \mathrm{sec}$ needs an irradiation time of 307.24 minutes; the boron dose of $130 \mu \mathrm{g} / \mathrm{g}$ and the dose rate of irradiation $0.00303389 \mathrm{~Gy} / \mathrm{sec}$ needs an irradiation time of 274.67 minutes; and the boron dose $150 \mu \mathrm{g} / \mathrm{g}$ and the dose rate of irradiation $0.00334565 \mathrm{~Gy} / \mathrm{sec}$ needs an irradiation time of 249.08 minutes. The Optimum concentration of boron is $150 \mu \mathrm{g} / \mathrm{g}$ with irradiation time of 249.08 minutes.
\end{abstract}

(C) 2019 IJPNA. All rights reserved.

\section{INTRODUCTION}

Cancer is the uncontrolled proliferation of cells or tissues. As mention by the Indonesian Health Ministry (2013), cancer is the 2nd leading cause of death $(13 \%$ from all $22 \%$ death) caused by non infected diseases in the world [Oemita et al, 2011]. Details of cancer caused death in Indonesia is 103,100 males and 92,200 females [WHO, 2014]. Frequent cancer cases that occur in males include lung cancer, prostate cancer and cholesterol cancer that translates to approximately $21.8 \%$ of all cancer cases, while in females, breast cancer equates to approximately $21.4 \%$ from all cancer cases.

\footnotetext{
*E-mail: sardjono.batan@gmail.com
}

BNCT is a new radiotherapy method that is being developed after many cancer therapies have displayed negative side effects towards patients. These methods include radiotherapy, surgery, chemotherapy and/or the combination of the three. Among the three methods as mentioned, BNCT is one radiotherapy method that has the potential to be developed.

Another important thing beside neutron sources and boron carrier for BNCT is setting the radiation dose received by the body, and so considering the quality of neutron radiation which is used for treatment [Huang, 2009]. These dosing devices must ensure the safety and optimal treatment. Safety means that the side effects of the treatment are limited to as little as possible. Optimal means the organ 
Volume 4, Number 1, February 2019, p. 8-11

e-ISSN 2550-0570, ( ) FSM UKSW Publication

affected by cancer receives as much treatment dose as possible and has an irradiation time that is as short as possible.

Research of BNCT has been done by Dian Noviati (2013) for breast cancer therapy. This research compares irradiation time in breast cancer with a boron concentration range of 20$70 \mu \mathrm{g} / \mathrm{g}$ using MCNP5. The results show that for BNCT the minimum irradiation time occurs when the boron concentration is $70 \mu \mathrm{g} / \mathrm{g}$ [Noviati, 2013]. Therefore, research about the dose received for breast cancer needs to be done so that safety and the optimum dose for BNCT treatment can be achieved.

\section{MATERIALS AND METHODS}

Design of the BSA and breast cancer were done using MCNPX. Dose distribution and irradiation time has been performed and calculated for each variation of boron concentration, i.e. $70 \mu \mathrm{g} / \mathrm{g}, 90 \mu \mathrm{g} / \mathrm{g}, 110 \mu \mathrm{g} / \mathrm{g}$, $130 \mu \mathrm{g} / \mathrm{g}$, and $150 \mu \mathrm{g} / \mathrm{g}$. The neutron energy used are epithermal neutrons with a flux of $8.05 \times 108$ neutron $/ \mathrm{cm}^{2} \mathrm{~s}$ [Gulo, 2012].

The cancer cells were made as a sphere with a diameter of $3 \mathrm{~cm}$, while the skin is a semi-circular shape with a thickness of 0.25 $\mathrm{cm}$, ribs are tubes with diameters of $1.5 \mathrm{~cm}$ and $15 \mathrm{~cm}$ in length, and the geometry of the breast is a half circle with a diameter of $14 \mathrm{~cm}$. In modeling, the cancer cells are considered to be situated in the middle of the breast. Cancer cell density is assumed to be $10 \%$ greater than the density of the normal breast tissue so that the density-value is $1.12 \mathrm{~g} / \mathrm{cm}^{3}$.

This research was conducted in several steps. The first step was to prepare the data and study library material. Second, to create the geometry of the cancer and healthy tissue that is placed in front of the BSA, then calculate the fraction of atoms to be used in data cards in MCNPX variation in the dose range of 70-150 $\mathrm{mg} / \mathrm{g}$. This is followed by running the program on each of the boron concentrations. The output of MCNPX will be analyzed to calculate the radiation dose and the time required for irradiation.

\section{RESULTS AND DISCUSSION}

Epithermal neutron flux is used in BNCT therapy so that the neutron is moderated when it passes through the body into thermal neutrons so that the energy received by the cancer under the surface is low, which reduces the dose received by the skin. Figure 2 (a and b) shows a side view of the NG BSA design and breast tissue. Every human being has varying characteristics and different breast sizes but the simulated breast size is based on the average breast size.

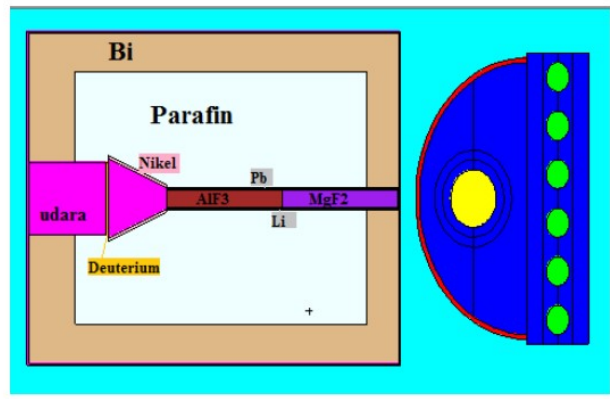

(a)

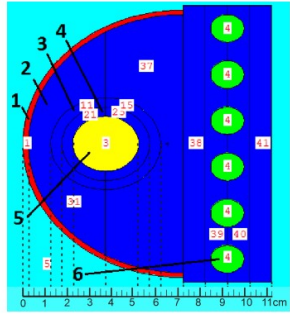

Information:

1. Skin

2. Healthy tissue

3. Planning Target Volume (PTV)

4. Clinical Target Volume (CTV)

5. Gross Tumor Volume (GTV)

6. Rib

(b)

Fig 1. Design of BSA and breast tissue use MCNPX (a) geometry of BSA and breast tissue design (b) geometry of breast tissue

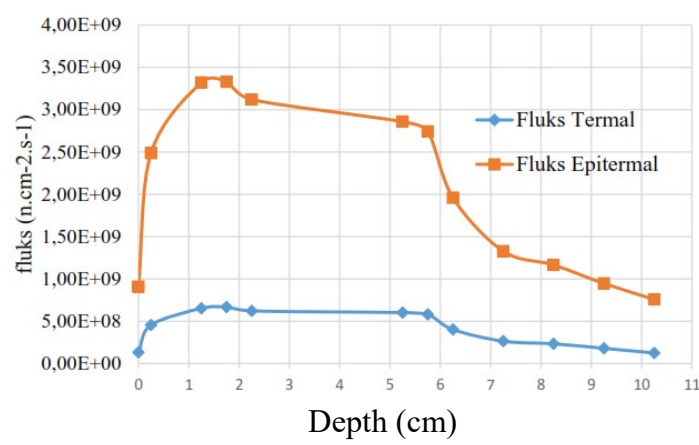

Fig 2. Neutorn flux due to the depth in tissue

Based on Figure 2, it is known that the epithermal neutron flux has a greater value than the thermal neutron flux, while the value of thermal neutron flux is below the epithermal 
neutrons and gradually declines faster until it approaches 0.00. Epithermal neutron flux increased with the depth of tissue, before declining. This happens because of the decreased energy of epithermal neutron (moderated) into thermal neutrons that interact with components of the tissue. The flux values obtained by the tissue will also affect the value of the total absorbed dose received by the tissues of the body.

Thermal and epithermal neutron flux at different tissue depths were obtained after concentrations of $10 \mathrm{~B}$ were varied in the cancer. The fourth dose also has each weight factor. Differences in factors are influenced by the sensitivity of the target tissue and Linear Energy Transfer (LET) of each dose. The weighting factors affect the value of the absorbed dose received by the tissues of the body. Table 1 shows the distribution of the dose rate in cancer tissues with various concentrations of boron.

Table 1. Dose rate in cancer cell

\begin{tabular}{|c|c|c|c|c|c|}
\hline \multirow{2}{*}{$\begin{array}{c}\text { Konsentrasi } \\
\text { boron } \\
(\mu \mathrm{g} / \mathrm{g})\end{array}$} & \multicolumn{5}{|c|}{ Laju dosis (Gy/detik) } \\
\cline { 2 - 7 } & $\dot{\mathrm{D} b}$ & $\dot{\mathrm{D} p}$ & $\dot{\mathrm{D} n}$ & $\dot{\mathrm{D} g}$ & Ḋtotal \\
\hline 70 & $3,21587 \mathrm{E}-04$ & $8,94055 \mathrm{E}-05$ & $3,47427 \mathrm{E}-04$ & $4,03500 \mathrm{E}-04$ & $2,93603 \mathrm{E}-03$ \\
\hline 90 & $4,42655 \mathrm{E}-04$ & $8,94055 \mathrm{E}-05$ & $1,82668 \mathrm{E}-05$ & $4,05389 \mathrm{E}-04$ & $2,41049 \mathrm{E}-03$ \\
\hline 110 & $5,23854 \mathrm{E}-04$ & $8,65683 \mathrm{E}-05$ & $1,78660 \mathrm{E}-05$ & $4,08407 \mathrm{E}-04$ & $2,71236 \mathrm{E}-03$ \\
\hline 130 & $6,10203 \mathrm{E}-04$ & $8,53242 \mathrm{E}-05$ & $1,75890 \mathrm{E}-05$ & $4,06384 \mathrm{E}-04$ & $3,03389 \mathrm{E}-03$ \\
\hline 150 & $6,93031 \mathrm{E}-04$ & $8,39852 \mathrm{E}-05$ & $1,73210 \mathrm{E}-05$ & $4,08210 \mathrm{E}-04$ & $3,34565 \mathrm{E}-03$ \\
\hline
\end{tabular}

Total dose rate at the cancerous tissue tends to increase for each increased boron concentration. This happens because healthy tissue only receives $0.3 \%$ of the boron the cancerous tissue receives. This value is obtained from the infusion method i.c ie with a ratio of 10: 1. Cancer received high doses, as high as the boron concentration that was injected into the body. This will speed up the healing process.

Table 2 shows the irradiation time required for each of the different boron concentrations in cancer tissue.
Table 2. Irradiation time due to boron concentration.

\begin{tabular}{|c|c|c|}
\hline $\begin{array}{c}\text { Konsentrasi boron } \\
(\mu \mathrm{g} / \mathrm{g})\end{array}$ & Waktu radiasi (detik) & Waktu radiasi (Menit) \\
\hline 70 & 24565,80 & 409,43 \\
\hline 90 & 20742,64 & 345,71 \\
\hline 110 & 18434,17 & 307,24 \\
\hline 130 & 16480,47 & 274,67 \\
\hline 150 & 14944,79 & 249,08 \\
\hline
\end{tabular}

In Table 2, the boron concentration of 70 $\mathrm{ug} / \mathrm{g}$ required an irradiation time of 409.43 minutes while the highest concentration of 150 $\mathrm{ug} / \mathrm{g}$ needed a faster time of 249.0824 minutes. Fast irradiation time is reached when the boron concentration is high, so that the dose rate in the cancer cell is high. This is because the high boron concentration can increase the probability of interaction between neutron and boron, thus affecting the production of the alpha particle which is used to kill the cancer.

Skin is one of the body tissues that will experience acute effects when exposed to radiation. The acute effects of this will occur after irradiation is done. Effects will arise normally in the form of erythema, moist desquamation and ulceration (pus). Erythema occurs when the skin receives a dose larger than 6 Gy while moist desquamation and ulceration occurs after receiving a dose of 20$25 \mathrm{~Gy}$. Therefore, the number of doses in the skin must be taken into consideration in the implementation of BNCT treatment so that the skin receives a dose of less than 6 Gy to avoid the effects of erythema (Novianti, 2013). Table 19 shows the results of the dose absorbed by each organ according to the result of calculations.

Table 3. Type Dose absorbed y each organs.

\begin{tabular}{|c|c|c|c|c|}
\hline \multirow{2}{*}{$\begin{array}{c}\text { Konsentrasi } \\
\text { boron } \\
(\mu \mathrm{g})\end{array}$} & \multicolumn{4}{|c|}{ Dosis Serap (Gy) } \\
\cline { 2 - 5 } & Kulit & Kanker & Payudara & Rusuk \\
\hline 70 & 2,9 & 50 & 5,2 & 2,7 \\
\hline 90 & 2,4 & 50 & 4,4 & 2,3 \\
\hline 110 & 2,1 & 50 & 3,8 & 1,9 \\
\hline 130 & 1,9 & 50 & 3,5 & 1,8 \\
\hline 150 & 1,8 & 50 & 3,1 & 1,7 \\
\hline
\end{tabular}

The table shows that the dose received by skin is less than 6 Gy when using a boron concentration of $150 \mathrm{ug} / \mathrm{g}$. The absorbed dose in the skin declines steadily with increasing concentrations of boron. The dose absorbed by other organs is reduced when granting enlarged concentrations as well, which is expected and 
is below the safe limit for each organ. In this study, the dose received by the skin, breast healthy tissue and ribs is at a concentration of $150 \mathrm{ug} / \mathrm{g}$, which is $1.8 \mathrm{~Gy}, 3.1 \mathrm{~Gy}$ and $1.7 \mathrm{~Gy}$, respectively. This shows that there are no side effects in the skin because the dose is within the safe level, ie below $2 \mathrm{~Gy}$, since epilation and dry desquamation occurs in the range of 3$12 \mathrm{~Gy}$.

\section{CONCLUSION AND REMARKS}

It can be concluded that the higher the concentration of boron in breast cancer therapy using BSA NG results in a lower irradiation time when the dose is within $70-150 \mathrm{mg} / \mathrm{g}$. The optimal dose of boron based on the results of the research is at a concentration of $150 \mathrm{ug} / \mathrm{g}$. The time required for the irradiation of breast cancer increases rapidly at concentrations greater than $150 \mathrm{ug} / \mathrm{g}$, with an irradiation time of 249.08 minutes or 4 hours 15 seconds.

\section{REFERENCES}

1. Kementerian Kesehatan RI. (2013). Riset Kesehatan Dasar. Jakarta: Badan Litbangkes, Depkes RI.

2. Oemita, R., E. Rahajeng dan A. Y. Kristanto. (2011). Prevalensi Tumor dan Beberapa Faktor yang Mempengaruhinya di Indonesia. Jakarta: Badan Penelitian dan Pengembangan Kesehatan.

3. World Health Statistic. (2014). Caner Country Profiles. World Health Organization Press. Hlm. 1-5.

4. Huang, J. (2009). Boron Neutron Capture Therapy for Cancer Treatments. Guildford: University of Surrey.

5. Noviati, D. (2013). Analisis Distribusi Dosis Radiasi pada Terapi Kanker Payudara dengan Boron Neutron Capture Therapy (BNCT) Mengggunakan MNCP5. Yogyakarta: Universitas Gadjah Mada.

6. International Atomic Energy Agency. (2001). Current Status of Neutron Capture Therapy. Wina: IAEA

7. Wolfgang, S., dan Ray, M. (2009). Requirement for Boron Neutron Capture Therapy (BNCT) at a Nuclear Research
Reactor. Belanda: The European BNCT Project.

8. Herman, C. \& Thomas E. J. (2009). Introduction to Health Physics, 4 Edition. McGraw-Hill, New York.

9. Fantidis, J. G., et al. (2013). Optimised BNCT Facility Based on a Compact D-D Neutron Generator. International Journal of Radiation Research, Vol. 11, No. 4, Hlm. 207-214.

10. Gulo, D. P., Suryasatriya, Santosa, S. \& Sardjono, Y. (2012). Desain Beam Shaping Aseembly (BSA) berbasis D-D Neutron Generator 2,45 MeV untuk Uji Fasilitas BNCT. Indonesian Journal of Applied Physics. Vol. 2 No. 2, Hlm. 138-142 